\title{
Influence of Management Quality and Technology Developments on Islamic Banking Performance in UAE
}

\author{
Mansoor Mulla, Ali Ameen, Ibrahim Alrajawy, Amiya Bhaumik
}

\begin{abstract}
A country's economic growth is said to be based on the finance sector and its performance, which is considered the most prominent factors in boosting an economy. Also, the economic stability and growth greatly depends on the stability and performance of its finance and banking sector. The study aims at examining the effect of quality management and development of technology in determining Islamic banking performance in the context of UAE. The process of evaluation was carried out using questionnaire survey data obtained from 158 valid responses from Customer Service Offers, Bank Managers, Front Line Officers, and Assistant Manager in the Islamic banks in the UAE. Structural Equation Modelling (SEM) was done using PLS3.0 software for determining the importance levels of associations within the tested factors. The goodness of fit of the proposed model showed $41 \%$ of variance in the Islamic banking performance. The multivariate analysis revealed that quality management has an impact on the Islamic banking performance as compared to technology development, which offers insights into the strategies of Islamic banking sector.
\end{abstract}

Keywords: Management quality; technology developments; Islamic banking; performance; UAE.

A country's economic growth is said to be dependent on finance sector performance, which is one of the most prominent factors amongst several other factors in boosting an economy. According to Siraj \& Pillai (2012) [1], the stability and growth of an economy depends on the stability and performance of its finance and banking sector. Today, Islamic banks are operating in many regions of the world, as a feasible and practical alternative system to the commercial or conventional banking system. Even though it was originally developed for the satisfaction of the requirements of Muslims [2], these banks have achieved an international acceptance and are recognised as one of the demanding areas in the finance and banking sector. At the moment, Islamic finance is being used in over sixty countries and is growing at a rate of $10 \%$ to $15 \%$ [3]. It is clear that Islamic banks have still been provided with enormous challenges within the global banking industry. In other words, since Islamic banking has recently come into the financial markets, it should come across various challenges in particularly reflecting noticeable performance in the current competitive environment.

Revised Manuscript Received on September 25, 2019

Mansoor Mulla, Lincoln University College, Selangor, Malaysia

Ali Ameen, Lincoln University College, Selangor, Malaysia

Ibrahim Alrajawy, Lincoln University College, Selangor, Malaysia

Amiya Bhaumik, Lincoln University College, Selangor, Malaysia

\section{INTRODUCTION}

To enhance the value of Islamic finance and banking, the management of its financial institutions should operate tactically and strategically to improve its different indicators of performance measurement with a greater care, while its principles are being complied with Sharia's laws and principles. It is clear that the UAE is trying to become a leading technology centre based on the innovation strategy of the 4th Industrial Revolution [4, 5]. As a consequence, Islamic banks should compete with commercial banking counterparts in the contexts of intra, as well as inter industry business, innovation, standardisation, and local and international markets in order to operate within the dual banking systems [6, 7]. Governments, organizations, and Individuals should pay the greatest attention to the planning and implementation of information technology in all its aspects of business, especially in the age of digitalization. In the age of digitalization, which has been commonly referred to Industry 4.0 or 4 th industrial revolution $[8,9]$.

The continuous developments in ICT (information and computer technology) have almost been affecting the most of industries operating in the world. In view of that, a similar impact can be noticed on the banking industry which is being tech-savvy [10]. The current automation and data exchange trend that has come up in the field of manufacturing technology that includes cyber-physical systems, the IoT, and cloud and cognitive computing [5, 11].

Several other alternative means have been offered to the banking sector with the advent of information technology in order to deal with the issues posed by the evolved economies. According to a report presented by the Gulf News in 2018 [12], two main important requirements of any contemporary banks are the core banking systems and digitisation [13]. In most contemporary organizations, adopting technology uses ICT in order to get hold of records as well as carry out the activities linked to identification, accumulation, analysis, measurement, preparation, interpretation and communication of the information used by management to plan. It is used in evaluating and controlling within an organization and to assure appropriate use and accountability for their resources [14-18].

Thus, the study aimed at examining the impact of quality of management and technology development on performance of Islamic banking sector in the UAE. 


\section{LITERATURE REVIEW}

\section{A. Management Quality (MQ)}

Management in general is referred to planning, organizing, coordinating, and controlling an organizational resource so as to reach towards its goals and objectives. Management comprises the activities such as setting the vision, mission, strategies, and goals and coordinating the employees' efforts to achieve the objectives by using various available sources of applications, such as financial, technological, and human resources [19]. Successful leadership and management stimulate enthusiasm and commitment, improving both employees and organizational performance.

Managerial skills are considered an important aspect of the manager's attributes in effectively managing his/her job roles in an organisation. Those with god level of skills can be instrumental in bringing efficiency in an organisation through increased performance. American Management Association (AMA) has shortlisted certain important set of managerial skills, such as conceptual skills, effectiveness, communication, and interpersonal skills. Welch studied various other effective managerial skills focusing on the competitive market, which includes the skills of multi-tasking, proactiveness, having a global vision, having a winning strategy, possessing the ability to maintain global-local balance, and skills of managing complexity [20]. To determine the UAE's global position in the world market, various global indicators have been formulated and used [21-24].

These qualities and skills are said to be crucial for managers to direct an organizational performance.

Concerning the banking industry, it has also been revealed that managerial effectiveness and efficiency has significant role to improving bank performance [25]. The study of Kehinde et al. (2015) [20] found that management and leadership skills have a significant relationship with banking performance. Molyneux \& Thornton (1992) [26], on the other hand, found a positive significant relationship between better-quality management of banks and their profitability. Hence, it is arguably evident that as a bank-specific factor, management has a critical association with its performance. Based on this, the following hypothesis has been proposed: H1: Management quality has a postive effect on Islamic banking performance.

\section{B. Technology Developments (TD)}

The paper of Webster (1997) [27] studies technological changes within the banking industry and its performance by using 225 banks, and found that technological change has significantly been associated with over-all banking performance. Frame \& White (2009) [28] and Berger \& DeYoung (2006) [29] found that technology changes improve efficiency, thereby bank performance. Moreover, he pointed out that a significant relationship has been shown between bank profitability and size and it had been affected by the rate at which the banks execute technological changes. The findings of Dangolani (2011) [30] study concluded that such significant relationship and particularly proved that IT contributes to banking systems in three diverse ways: IT saves the customers and the employees' time noticeably; IT reduces the expenses; and IT enables the network transactions.

On the other hand, by using a sample of 3,190 banks from 17 countries, Campanella, Peruta, \& Del Giudice (2015) [31] studied the influence of new technologies on the structure and behaviour of banks. The researchers listed out the negative relation within the two technological innovations with respect to enterprise resource planning (ERP) software systems and credit risk management software and financial leverage. ERP affects the abilities, competences, and organisation of banking systems. Any innovations in this field would lead to increase in the earning margin of the banks, and finally, its performance. This led to proposal of the second hypothesis: $\mathrm{H} 2$ : Technology developments has a postive effect on Islamic banking performance.

\section{Islamic Banking Performance (IBP)}

Warde (2000) [32] explains Islamic finance as "the Islamic financial institutes in their aims and operations depend on the Quranic or Islamic principles". While the organizational performance is a benchmark or an indicator for efficiency, effectiveness, and environmental obligation like productivity, time of cycle, reduction of waste, and compliance of rules [33].

Despite all the facts and significant development of Islamic banking, the literature has still shown the lack of focus toward the efficiency of the Islamic banks $[34,35]$. Since, it is found that most of the studies and researches in literature are generally focusing on the presentation of two types of banks; the Islamic financial intermediaries and the conventional banks with respect to the relationship between the features of the banks and their profitability. For instance, Sufian \& Noor (2009) [36] and Khrawish (2011) [37] utilized bank level data in their researches and performed regression analysis in order to scrutinize the determinants associated with the performance of the Islamic Banks. Similarly, Safiullah (2010) [38] conducted a study on the working of Islamic banking in Bangladesh in order to measure the efficiency of banks by using Banking Efficiency Model. In this research, researcher confirmed that the Islamic banks have potential to stay dynamic even in the conventional banking architecture where the profit and loss sharing methods of investments are of minimum dominance. Along with this, the researcher also found that the financial services and financial products in the Islamic the banking system possess different risk aspects therefore different prudential regulations have to be adopted [38].

In addition to the above, Samad (2004) [39] has done a comparative study for measuring the performance of Islamic and the conventional banks in Bahrain by using nine financial ratios. These financial ratios were based on profitability, liquidity, and credit risk. His study has also applied the Student's t-test. The results of the study concluded with the fact that there exist considerable difference among the working of Islamic and conventional banks related to the credit in Bahrain, while no such different has been recognized with

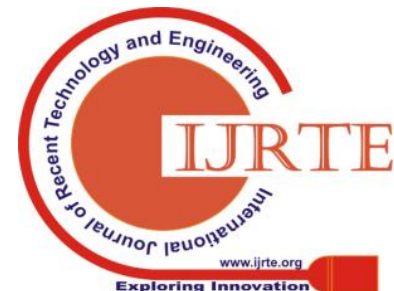


respect to the profitability and the liquidity ratios [39].

\section{RESEARCH METHOD}

\section{A. Overview of the Proposed Conceptual Framework}

In this study, the primary objective is to investigate the relationship between management quality, and technology development and the Islamic banking performance. An extensive review of literature has highlighted the variables of this study and RBV as underpinning theory. In this regard, management quality and technology development are deemed to be a distinct intangible competitive advantage resource. Figure 1 depicts the proposed conceptual model that includes management quality, and technology development and the Islamic banking performance.

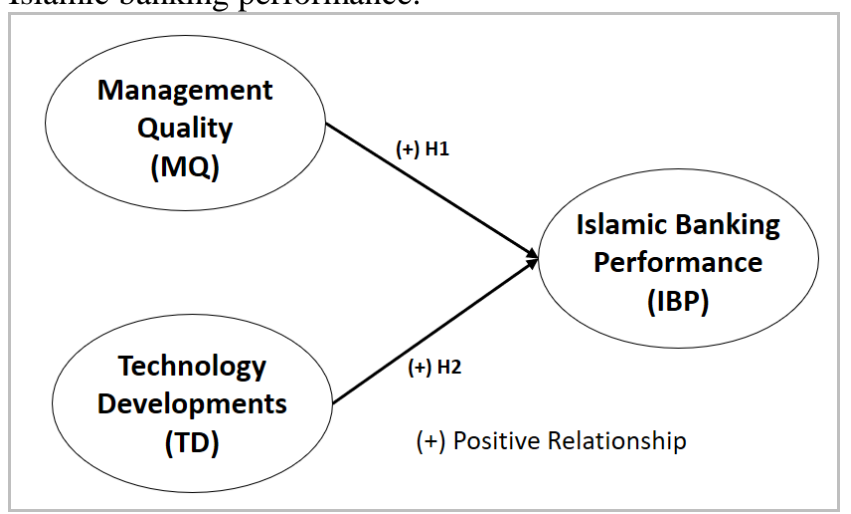

Fig. 1. The proposed conceptual framework

\section{B. Development of Instrument and Data collection}

The survey research was carried out in the UAE's banks within a period of six months beginning from April 2018 to end of September 2018. This study distributed 200 questionnaire copies and expected a high response rate, and the final collected data samples numbered 158 from Customer Service Offers, Bank Managers, Front Line Officers, and Assistant Manager in the Islamic banks in the UAE. A random sample sampling was used as per Creswell (2003) [40]. The questionnaire collected data are analysed with the help of analytical methods, and in the present study, data analysis was conducted with the help of Statistical Package of Social Sciences (SPSS), version 22.0 and Smart PLS3.0. The data analysis methods adopted based on their research questions and the characteristics of the variables as recommended by Byrne (2010) [41]. Variables were measured using a Likert Scale which recommended in the previous studies [42, 43].

\section{DATA ANALYSIS AND RESULTS}

PLS (Partial Least Squares) SEM-VB (Structural Equation Modelling-Variance Based) was used for the assessment of the proposed research model using SmartPLS 3.0 software [44]. A two-phase analytical technique [45] consisting of (i) measurement model analysis (reliability and validity) and (ii) structural model analysis (examining the conceptualised Table-I: Measurement assessment results relationships) was employed after performing the descriptive assessment.

\section{A. Descriptive analysis}

Table 1 shows the values for mean and SD for each study variable. The respondents were asked to indicate their opinion in relation to management quality, technology developments, and Islamic banking performance based on a 5-point scale ranging from 1 (strongly disagree) to 5 (strongly agree). Technology developments score the highest with mean 4.355 out of 5.0, with a standard deviation of 0.460 .

\section{B. Measurement Model Assessment}

Construct reliability as well as validity (comprising discriminant and convergent validity) were used to examine the measurement model. The particular alpha coefficients of Cronbach were tested to determine the reliability of every core parameter in the measurement model (construct reliability). The quantities of all the unique alpha coefficients of Cronbach in this research ranged from 0.840 to 0.897 , which went beyond the proposed value of 0.7 [46]. Moreover, for inspecting construct reliability, all the CR (composite reality) values ranged from 0.887 to 0.921 , which went beyond 0.7 [47-49]. Thus, as Table 1 shows, construct reliability has been fulfilled as Cronbach's CR and alpha were rather error-free for all the parameters.

Analysis of indicator reliability was conducted by utilising factor loadings. When the related indicators are very similar, this is reflected in the construct and signified by the construct's high loadings [50]. As per Hair et al. (2010) [51], the exceeding of values beyond 0.70 suggests substantial factor loadings. Table 1 displays that all items in this research had factor loadings greater than the suggested value except for item QM1, TD7, IBP1, and IBP6 which were eliminated from the scale due to low loadings..

AVE (average variance extracted) was employed in this study to analyse convergent validity, which represents the degree to which a measure is correlated positively with the same construct's other measures. All the AVE values ranged from 0.597 and 0.661 , which went beyond the proposed value of 0.50 [51]. Thus, all constructs have complied with the convergent validity acceptably, as shown in Table 1.

The degree to which the articles distinguish among concepts or measure different constructs is demonstrated by discriminant validity. Fornell-Larcker criterion was used for analysis of discriminant validity of the measurement model. Table 2 shows the outcomes for discriminant validity by employing the Fornell-Larcker condition. It was discovered that the AVEs' square root on the diagonals (displayed in bold) is bigger than the correlations among constructs (corresponding row as well as column values), suggesting a strong association between the concepts and their respective markers in comparison to the other concepts in the model [52, 53]. 
Influence of Management Quality and Technology Developments on Islamic Banking Performance in UAE

\begin{tabular}{|c|c|c|c|c|c|c|c|}
\hline Constructs & Item & $\begin{array}{c}\text { Loading } \\
(>0.7)\end{array}$ & Mean & SD & $\begin{array}{c}\alpha \\
(>0.7)\end{array}$ & $\begin{array}{c}\text { CR } \\
(>0.7)\end{array}$ & $\begin{array}{c}\text { AVE } \\
(>0.5)\end{array}$ \\
\hline \multirow{7}{*}{$\begin{array}{l}\text { Management } \\
\text { Quality } \\
\text { (MQ) }\end{array}$} & MQ1 & Deleted & \multirow{7}{*}{3.973} & \multirow{7}{*}{0.529} & \multirow{7}{*}{0.897} & \multirow{7}{*}{0.921} & \multirow{7}{*}{0.661} \\
\hline & MQ2 & 0.754 & & & & & \\
\hline & MQ3 & 0.866 & & & & & \\
\hline & MQ4 & 0.736 & & & & & \\
\hline & MQ5 & 0.790 & & & & & \\
\hline & MQ6 & 0.861 & & & & & \\
\hline & MQ7 & 0.861 & & & & & \\
\hline \multirow{7}{*}{$\begin{array}{l}\text { Technology } \\
\text { Developments } \\
\text { (TD) }\end{array}$} & TD1 & 0.745 & \multirow{7}{*}{4.355} & \multirow{7}{*}{0.460} & \multirow{7}{*}{0.867} & \multirow{7}{*}{0.899} & \multirow{7}{*}{0.597} \\
\hline & TD2 & 0.824 & & & & & \\
\hline & TD3 & 0.728 & & & & & \\
\hline & TD4 & 0.797 & & & & & \\
\hline & TD5 & 0.772 & & & & & \\
\hline & TD6 & 0.765 & & & & & \\
\hline & TD7 & Deleted & & & & & \\
\hline \multirow{7}{*}{$\begin{array}{c}\text { Islamic Banking } \\
\text { Performance (IBP) }\end{array}$} & IBP1 & Deleted & \multirow{7}{*}{4.078} & \multirow{7}{*}{0.433} & \multirow{7}{*}{0.840} & \multirow{7}{*}{0.887} & \multirow{7}{*}{0.612} \\
\hline & IBP2 & 0.730 & & & & & \\
\hline & IBP3 & 0.813 & & & & & \\
\hline & IBP4 & 0.778 & & & & & \\
\hline & IBP5 & 0.737 & & & & & \\
\hline & IBP6 & Deleted & & & & & \\
\hline & IBP7 & 0.847 & & & & & \\
\hline
\end{tabular}

Note: $\mathrm{SD}=$ Standard Deviation, $\alpha=$ Cronbach's alpha; $\mathrm{CR}=$ Composite Reliability, AVE = Average Variance Extracted.

This indicates good discriminant validity. Furthermore, the exogenous constructs have a correlation of less than 0.85
[54]. Therefore, all constructs had their discriminant validity fulfilled satisfactorily.

Table-II: Fornell-Larcker criterion

\begin{tabular}{l|lll}
\hline & $I B P$ & $Q M$ & $T D$ \\
\hline IBP & $\mathbf{0 . 7 8 2}$ & & $\mathbf{0 . 8 1 3}$ \\
QM & 0.616 & 0.441 & $\mathbf{0 . 7 7 3}$ \\
TD & 0.429 & 0.49 & \\
\hline
\end{tabular}

Note: Diagonals represent the square root of the average variance extracted while the other entries represent the correlations.

Key: MQ: Management Quality, TD: Technology Developments, IBP: Islamic Banking Performance

\section{Structural Model Assessment}

The structural model can be tested by computing beta $(\beta)$, $\mathrm{R}^{2}$, and the corresponding t-values via a bootstrapping procedure with a resample of 5,000.

Figure 2 and Table 3 depict the structural model assessment, showing the results of the hypothesis tests. Management quality and technology developments positively influence Islamic banking performance. Hence, $\mathrm{H} 1$ and $\mathrm{H} 2$ are accepted with $(\beta=0.529, \mathrm{t}=7.471, \mathrm{p}<0.001)$ and $(\beta=0.196, \mathrm{t}=3.002, \mathrm{p}<0.01) \quad$ respectively. Forty-one percent of the variance in Islamic banking performance is explained by Management quality and technology developments. The values of $\mathrm{R}^{2}$ have an acceptable level of explanatory power, indicating a substantial model $[53,55]$.

\section{DISCUSSION}

The main objective of this research is to examine the impact of management quality, and technology development on the Islamic banking performance in the UAE. Results are promising as they are discussed below:

First, the regression paths between management qulaity and bank performance for Islamic bank performance, model was scrutinised. The relationship between management, which is a composite construct, and Islamic bank performance was revealed to be positive and statistically significant at the confidence level of 0.05 , and thus, supporting the hypothesis H1 with $(\beta=0.529, \mathrm{t}=7.471, \mathrm{p}<0.001)$. This result is consistent with previous studies that scrutinised the impact of management on bank performance [20, 25, 26]. For instance, Kehinde et al. (2015) [20] showed that management skills have a significant and positive association with banking performance, while Soyibo \& Adekany (1992) [25] found that efficiency and effectiveness of management has a significant role in enhancing bank performance. However, these studies had been taken place in the context of commercial bank performance, indicating a lack of studies relating to Islamic bank performance and management, for which this study contributed.

Second, the investigation into the effect of technology development on bank 


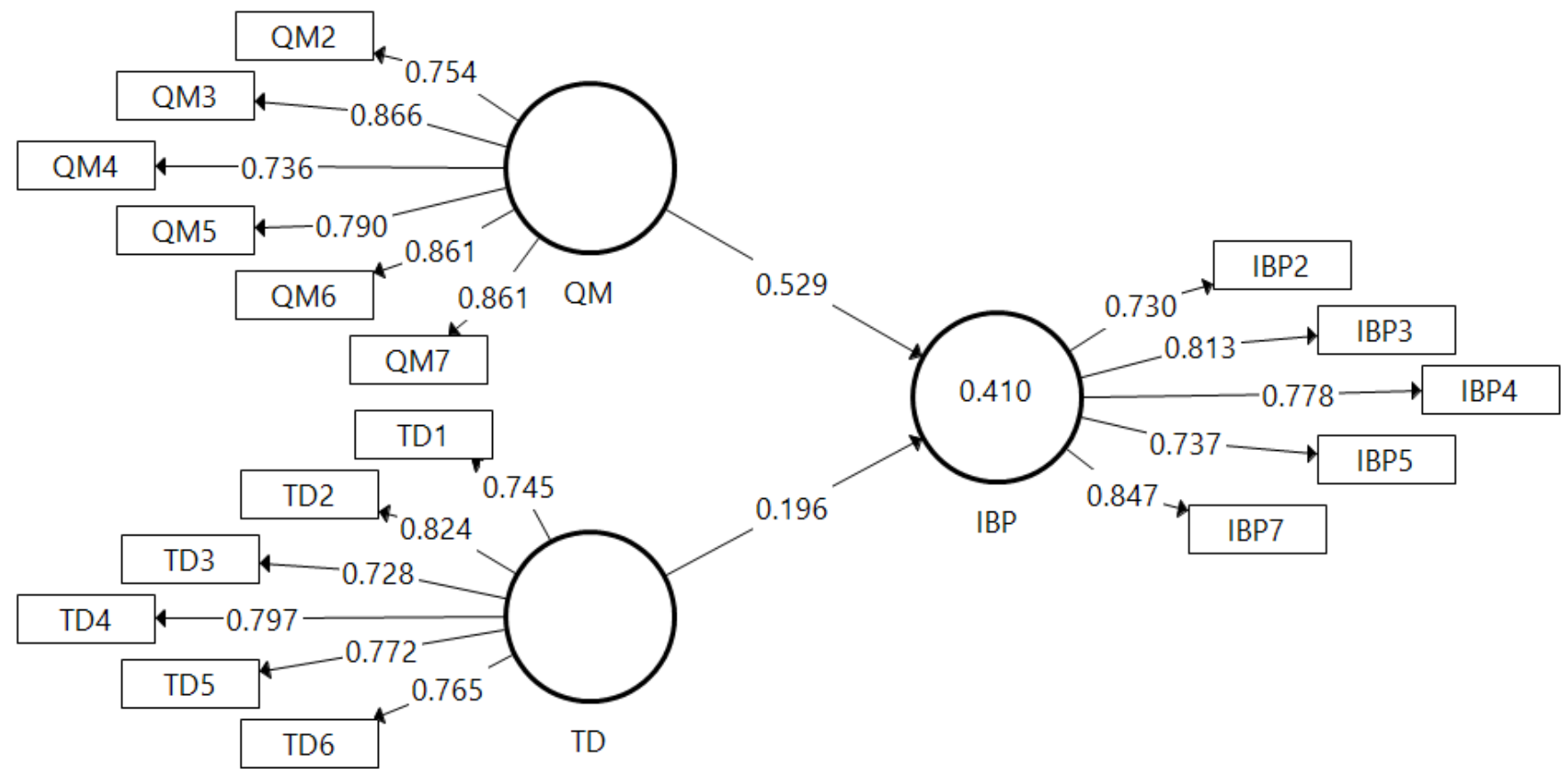

Key: MQ: Management Quality, TD: Technology Developments, IBP: Islamic Banking Performance Fig. 2. PLS algorithm results

Table-III: Structural path analysis result

\begin{tabular}{clllcccc}
\hline \hline Hypothesis & \multicolumn{1}{c}{ Relationship } & Std Beta & Std Error & t-value & p-value & Decision & $\mathrm{R}^{2}$ \\
\hline H1 & MQ $\rightarrow$ IBP & 0.529 & 0.071 & 7.471 & 0.000 & Supported & 0.41 \\
H2 & TD $\rightarrow$ IBP & 0.196 & 0.065 & 3.022 & 0.001 & Supported \\
\hline \hline
\end{tabular}

Key: MQ: Management Quality, TD: Technology Developments, IBP: Islamic Banking Performance

performance, was attained through. Accordingly, the results showed that there is positive and statistically significant effect of technology development on Islamic bank performance ( $\beta=0.196, \mathrm{t}=3.002, \mathrm{p}<0.01)$, and therefore, the hypothesis 2 is accepted. [27-30, 56]. For instance, Webster (1997) [27] found that technological changes in the banking sector has significant and positive association with over-all banking performance, Hilal (2015) [56] confirmed that new technologies are critically important for the development of the banking sector, strengthening their profitability. However, these studies were related to commercial banking performance, indicating a lack of research papers investigating into the effect new technology changes and Islamic bank performance. Furthermore, studies have shown technology development greatly contributes towards achieving bank efficiency, and thereby bank performance. Frame \& White (2009) [28] found that technological changes have a positive impact on financial innovation, whereby efficiency of banks can be improved, while Berger \& DeYoung (2006) [29] proved technological developments helps the banks' geographical expansion by decreasing distant-related agency costs efficiently.

Ultimately, the two specific objectives of this research were achieved and results found that management qulaity and technology developemnt have positive direct impact on the islamic banking performance in the UAE, although, management quality has more impact on the performance, yet technology development has a great impact on the performance. Finally the variance explained in this study is $41 \%$ which is considered high.

\section{CONCLUSION}

The researcher conducted this study in view of the fact that more detailed picture about islamic banking performance and their critical factors can statistically be investigated by using questionnaire method as it provides an insight into different views and opinions of islamic banking professionals in the UAE with regard to bank management qulaity and technological development. The tow proposed hypothesis were supported statistically. The conclusion derived from the present study is that management quality and technology development positively and significantly contributed to the Islamic banking performance in UAE. These factors are relatively important techniques that contributed to the performance Islamic banking firms in UAE, since their explanation of the total variance $41 \%$. As a result, this study empirically reveals that Islamic bank in the UAE ought to critically employ the management factor, by profoundly focusing on bank's vision, mission and objectives, change management (to cope with business environmental changes), effective HRM practices, and development of innovative mangers. The result further showed that Leadership \& management capability towards quick technology adoption, and Effective adaption to new technology banking staff were equally important for Islamic banking system. Particularly in the UAE. Results would give insights for Islamic banking sector in the UAE to improve the performance focusing on management quality and technology development. 
Appendix

Appendix A

Instrument for varibles

\begin{tabular}{|c|c|c|}
\hline Varible & Measure & Source \\
\hline $\begin{array}{c}\text { Management } \\
\text { Quality } \\
\text { (MQ) }\end{array}$ & $\begin{array}{l}\text { QM1: The experienced and educated management team are leading the bank. } \\
\text { QM2: There are effective leadership and management approaches and practices } \\
\text { at the bank. } \\
\text { QM3: All levels of management are committed towards the achievement of the } \\
\text { bank's vision, mission, and objectives. } \\
\text { QM4: Successful strategies are developed and implemented in line with } \\
\text { business environmental changes. } \\
\text { QM5: Good HRM practices have been placed. } \\
\text { QM6: Managers are more innovative. } \\
\text { QM7: Manager is well-versed with problem-solving skills. }\end{array}$ & {$[19,26]$} \\
\hline $\begin{array}{l}\text { Technology } \\
\text { Developments } \\
\text { (TD) }\end{array}$ & $\begin{array}{l}\text { TD1: The bank is utilizing up-to-date information and communication } \\
\text { technology } \\
\text { TD2: Innovative technologies that ease the bank's operations are improving } \\
\text { TD3: The quality of services of e-banking, mobile banking provided by the } \\
\text { bank improving } \\
\text { TD4: Research \& development activities in the UAE's banking industry have } \\
\text { been enhancing } \\
\text { TD5: Leadership \& management capability towards technology adoption at the } \\
\text { bank is good } \\
\text { TD6: The bank's staff is effectively adopting new technologies } \\
\text { TD7: The bank is highly focusing on the digital vision }\end{array}$ & {$[28,29]$} \\
\hline $\begin{array}{c}\text { Islamic } \\
\text { Banking } \\
\text { Performance } \\
\text { (IBP) }\end{array}$ & $\begin{array}{l}\text { IBP1: The bank's revenue and profitability is improving } \\
\text { IBP2: The number of customers/deposits/loans are increasing } \\
\text { IBP3: Successful innovative finance products have been launching } \\
\text { IBP4: The bank's overall assets are improving } \\
\text { IBP5: Non-current assets are being utilized efficiently } \\
\text { IBP6: The bank is maintaining adequate capital } \\
\text { IBP7: Good asset \& liability management practices have been placed }\end{array}$ & {$[36,37]$} \\
\hline
\end{tabular}

\section{REFERENCES}

1. K. Siraj \& S. Pillai (2012). Comparative Study on Performance of Islamic Banks and Conventional Banks in GCC Region. Journal of Applied Finance and Banking. Vol. 2.

2. S. A. Srairi (2009). Cost and profit efficiency of conventional and Islamic banks in GCC countries. Journal of Productivity Analysis, Vol. 34(1), pp. 45-62.

3. S. Haron \& N. W. Azmi (2009). ISLAMIC FINANCE BANKING SYSTEM. McGraw-Hill.

4. A. S. Alkhateri, A. E. Abuelhassan, G. S. A. Khalifa, M. Nusari \& A. Ameen (2018). The Impact of perceived supervisor support on employees turnover intention: The Mediating role of job satisfaction and affective organizational commitment. International Business Management, Vol. 12(7), pp. 477-492.

5. A. Ameen, H. Almari, \& O. Isaac (2019). Determining Underlying Factors that Influence Online Social Network Usage Among Public Sector Employees in the UAE. In Fathey M. Faisal Saeed, Nadhmi Gazem (Ed.), Recent Trends in Data Science and Soft Computing. IRICT 2018. Advances in Intelligent Systems and Computing (Recent Tre, Vol. 843, pp. 945-954). Springer Nature Switzerland AG: Springer International Publishing.

6. A. Belouafi \& A. Chachi (2014). Islamic Finance in the United Kingdom: Factors Behind its Development and Growth. Islamic Economic Studies. Vol. 22. https://doi.org/10.12816/0004130

7. J. Bley \& K. Kuehn (2004). Conventional versus Islamic finance: Student knowledge and perception in the United Arab Emirates. International Journal of Islamic Financial Services. Vol. 5.

8. Q. A. Al-Maamari, R.-N.Kassim, V. Raju, A. Al-Tahitah, A. Ameen, M. Abdulrab, M. Abdulrab (2018). Factors Affecting Individual Readiness for Change: A Conceptual Framework. International Journal of Management and Human Science, Vol. 2(1), pp. 13-18.

9. N. Lwin, A. Ameen \& M. Nusari (2019). Mobile Banking Adoption among Customers within Private Commercial Banking Sector in Yangon, Myanmar. International Journal of Management and Human Science (IJMHS), Vol. 3(2), pp. 44-59.
10. D. Cogan (2008). Corporate Governance and Climate Change: The Banking Sector.

11. A. Ameen, H. Almari \& O. Isaac (2018). Determining Underlying Factors that Influence Online Social Network Usage among Public Sector Employees in the UAE. In B. A. Saeed F., Gazem N., Mohammed F. (Ed.), 3rd international conference on reliable information and communication technology 2018 (IRICT 2018), Bangi-Putrajaya, Malaysia (3rd ed., Vol. 843, pp. 945-954). Cham: Springer, Cham.

12. Gulf News. (2018). Evolution of technology in the banking sector.

13. S. Sassi \& M. Goaied (2013). Financial development, ICT diffusion and economic growth: Lessons from MENA region. Telecommunications Policy, Vol. 37(4-5), pp. 252-261. https://doi.org/10.1016/j.telpol.2012.12.004

14. A. Ameen \& K. Ahmad (2011). The Role of Finance Information Systems in anti financial corruptions: A theoretical review. In 11 International Conference on Research and Innovation in Information Systems (ICRIIS'11 (pp. 267-272). Ieee. https://doi.org/10.1109/ICRIIS.2011.6125725

15. A. Ameen \& K. Ahmad (2012). Towards Harnessing Financial Information Systems in Reducing Corruption : A Review of Strategies. Australian Journal of Basic and Applied Sciences, Vol. 6(8), pp 500-509.

16. A. Ameen \& K. Ahmad (2013a). A Conceptual Framework of Financial Information Systems to reduce corruption. Journal of Theoretical and Applied Information Technology, Vol. 54(1), pp. 59-72.

17. A. Ameen \& K. Ahmad (2013b). Proposing Strategy for Utilizing Financial Information Systems in Reducing Corruption. In 3rd International Conference on Research and Innovation in Information Systems - 2013 (ICRIIS'13) (Vol. 2013, pp. 75-80).

18. A. Ameen \& K. Ahmad (2014). A Systematic Strategy for Harnessing Financial Information Systems in Fighting Corruption Electronically. In Knowledge Management International Conference (KMICe) 2014, 12 - 15 August 2014, Malaysia (pp. 12-15). Retrieved from http://www.kmice.cms.net.my/ 
19. D. Simandan (2018). Iterative lagged asymmetric responses in strategic management and long-range planning. Time \& Society, 0961463X17752652. https://doi.org/10.1177/0961463X17752652

20. J. Kehinde, Akomolafe, O. Oni E. Bosede \& A. Mark (2015). Public Debt and Private Investment in Nigeria. American Journal of Economics (Vol.

2015) https://doi.org/10.5923/j.economics.20150505.10

21. W. Al-Ali, A. Ameen, O. Issac, M. Nusari \& Ibrhim Alrajawi. (2018) Investigate the Influence of Underlying Happiness Factors on the Job Performance on the Oil and Gas Industry in UAE. International Journal of Management and Human Science (IJMHS), Vol. 2(4), pp 32.

22. F. Al-Obthani, A. Ameen, M. Nusari \& I. Alrajawy (2018). Proposing SMART-Government Model: Theoretical Framework. International Journal of Management and Human Science (IJMHS), Vol. 2(2), pp. 27-38

23. R. Al-Shamsi, A. Ameen, O. Isaac, A. H. Al-Shibami \& G. Sayed Khalifa, (2018). The Impact of Innovation and Smart Government on Happiness: Proposing Conceptual Framework. International Journal of Management and Human Science (IJMHS), Vol. 2(2), pp. 10-26.

24. A. Haddad, A. Ameen \& M. Mukred (2018). The Impact of Intention of Use on the Success of Big Data Adoption Via Organization Readiness Factor. International Journal of Management and Human Science (IJMHS), Vol. 2(1), pp. 43-51.

25. A. Soyibo \& F. Adekanye (1992). Financial system regulation, deregulation and savings mobilization in Nigeria. In AERC research paper;11. Nairobi: African Economic Research Consortium.

26. P. Molyneux \& J. Thornton (1992). Determinants of European Bank Profitability: A Note. Journal of Banking \& Finance. Vol. 16 https://doi.org/10.1016/0378-4266(92)90065-8

27. A. L. Webster (1997). The impact of technological change on bank performance. Journal of Economics and Finance, Vol. 21(3), pp. 41-47.

28. W. S. Frame \& L. J. White (2009). Technological Change, Financial Innovation, and Diffusion in Banking. Working Paper Series.

29. A. N. Berger \& R. DeYoung (2006). Technological Progress and the Geographic Expansion of the Banking Industry. Journal of Money, Credit and Banking, Vol. 38(6), pp. 1483-1513.

30. S. K. dangolani (2011). The Impact of Information Technology in Banking System (A Case Study in Bank Keshavarzi IRAN). Procedia Social and Behavioral Sciences, Vol. 30, pp. 13-16. https://doi.org/https://doi.org/10.1016/j.sbspro.2011.10.003

31. F. Campanella, M. Peruta \& M. Del Giudice (2015). The Effects of Technological Innovation on the Banking Sector. Journal of the Knowledge Economy Vol. https://doi.org/10.1007/s13132-015-0326-8

32. I. Warde (2000). Islamic finance in the global economy. Edinburgh University Press.

33. W. N. MUCHIRA (2013). RELATIONSHIP BETWEEN STRATEGY IMPLEMENTATION AND PERFORMANCE IN COMMERCIAL BANKS IN KENYA. UNIVERSITY OF NAIROBI.

34. M. Cihak \& H. Hesse (2010). Islamic Banks and Financial Stability: An Empirical Analysis. IMF Working Papers. Vol. 38 https://doi.org/10.1007/s10693-010-0089-0

35. F. Sufian (2007). The efficiency of Islamic banking industry in Malaysia. Humanomics: The International Journal of Systems and Ethics Vol. 23. https://doi.org/10.1108/08288660710779399

36. F. Sufian \& M. A. N. M. Noor (2009). The determinants of Islamic banks' efficiency changes: Empirical evidence from the MENA and Asian banking sectors. International Journal of Islamic and Middle Eastern Finance and Management, Vol. 2(2), pp. 120-138. https://doi.org/10.1108/17538390910965149

37. H. A. Khrawish (2011). Determinants of Commercial Banks Performance: Evidence from Jordan. International Research Journal of Finance and Economics. Vol. 81.

38. M. Safiullah (2010). Superiority of Conventional Banks \& Islamic Banks of Bangladesh: A Comparative Study. International Journal of Economics and Finance. Vol. 2. https://doi.org/10.5539/ijef.v2n3p199

39. A. Samad (2004). Bahrain Commercial Bank's Performance during 1994-2001. Credit and Financial Management Review. Vol. 10.

40. J. W. Creswell (2003). Research design Qualitative quantitative and mixed methods approaches. Research Design Qualitative Quantitative and Mixed Methods Approaches, pp. 3-26. https://doi.org/10.3109/08941939.2012.723954

41. B. M. Byrne (2010). Structural Equation Modeling With AMOS: Basic Concepts, Applications, and Programming (2nd ed.). Routledge.

42. A. H. Aldholay, Z. Abdullah, T. Ramayah, O. Isaac \& A. M. Mutahar (2018). Online learning usage and performance among students within public universities in Yemen. Int. J. Services and Standards, Vol. 12(2), pp. 163-179.

43. A. M. Mutahar, N. M. Daud, T. Ramayah, O. Isaac \& I. Alrajawy (2017). Examining the intention to use mobile banking services in Yemen: an integrated perspective of technology acceptance model (TAM) with perceived risk and self-efficacy. Asian Journal of Information Technology, Vol. 15(12).

44. C. M. Ringle, S. Wende \& J.-M. Becker (2015). SmartPLS 3. Bonningstedt: SmartPLS

45. J. C. Anderson \& D. W. Gerbing (1988). Structural Equation Modeling in Practice: A Review and Recommended Two-Step Approach. Psychological Bulletin, Vol. 103(3), pp. 411-423. https://doi.org/10.1037/0033-2909.103.3.411

46. V. R. Kannana \& K. C. Tan (2005). Just in time, total quality management, and supply chain management: understanding their linkages and impact on business performance. Omega: The International Journal of Management Science, Vol. 33(2), pp. $153-162$.

47. C. E. Werts, R. L. Linn \& K. G. Jöreskog (1974). Intraclass reliability estimates: Testing structural assumptions. Educational and Psychological Measurement, Vol. 34(1), pp. 25-33.

48. R. B. Kline (2010). Principles and practice of structural equation modeling (3rd ed.). New York: The Guilford Press

49. D. Gefen, D. Straub \& M.-C. Boudreau (2000). Structural equation modeling and regression: Guidelines for research practice. Communications of the Association for Information Systems, Vol. 4(1), pp. 1-79.

50. J. F. J. Hair, G. T. M. Hult, C. Ringle \& Sarstedt, M. A Primer on Partial Least Squares Structural Equation Modeling (PLS-SEM), 46 Long Range Planning $\S$ (2014). London: Thousand Oaks: SAGE. https://doi.org/10.1016/j.lrp.2013.01.002

51. J. F. Hair, W. C. Black, B. J. Babin \& R. E. Anderson (2010) Multivariate Data Analysis. New Jersey.

52. C. Fornell \& D. F. Larcker (1981). Evaluating structural equation models with unobservable variables and measurement error. Journal of Marketing Research, Vol. 18(1), pp. 39-50.

53. W. W. Chin (1998a). Issues and opinion on structural equation modeling. MIS Quarterly, Vol. 22(1), pp. 7-16.

54. Z. Awang (2014). Structural Equation Modeling Using AMOS. Shah Alam.Malaysia: University Teknologi MARA Publication Center.

55. J. Cohen (1988). Statistical Power Analysis for the Behavioral Sciences (2nd Editio). LawreAssociatesnce Erlbaum.

56. M. Hilal (2015). Technological Transition of Banks for Development New Information and Communication Technology and Its Impact on the Banking Sector in Lebanon. International Journal of Economics and Finance, Vol. 7(5), pp. 186-200 https://doi.org/10.5539/ijef.v7n5p186

\section{AUTHORS PROFILE}

Mansoor Mulla Lincoln University College, Selangor, Malaysia

Ali Ameen Lincoln University College, Selangor, Malaysia

Ibrahim Alrajawy Lincoln University College, Selangor, Malaysia

Amiya Bhaumik Lincoln University College, Selangor, Malaysia 